\title{
Editorial
}

\section{The Qur'an as Matrix of Islamic Civilization and Society}

Societies are generally seen as producers of texts. Islam suggests that texts are producers of society, especially texts that record divine revelation from prophets and messengers. In the genre of literature that deals with the miraculous nature ( $i$ jaz) of the Qur'an, various authors have sought to demonstrate the miracle of the Qur'an on various grounds: the compelling and matchless esthetic beauty of the Arabic; the quality of information and knowledge contained in the Book, either "scientific" or "religious"; and its miraculous transformative power, by which a new civilization was created through the work of devout believers whose souls had been changed. The unprecedented advance in civilization associated with Islam's spread is offered as sufficient proof. Thus Islamic civilization is seen to have an umbilical relationship with the Qur'an as revelation and text. Just as the Qur'an itself speaks of the umm alkitab, bringing motherhood fully into the divine economy, Muslims and their societies may be seen as children and progeny of the Qur'an, their mother. Such a sense is heightened when one remembers that the most frequently invoked attribute of God is Rahmah (mercy), whether as al-Rahman or as al-Rahim, and that these attributes share their etymology with the word rahim (womb), a symbol of unconditional and naturally given protection, nourishment, solicitude, and love.

This veneration of and dependency on the written word is one of the hallmarks of what Hodgson termed "islamicate societies." Islamic culture's textual output is of course impossible to tabulate properly, covering as it it does a vast and heretofore unimaginable range of subjects, genres, and functions. This issue of the journal offers just a glimmer of the kind of truly dazzling variety of intellectual and artistic pursuits that found themselves simultaneously influencing and influenced by their respective social contexts. With Sebastian Günther's article we are treated to a scholarly exploration of the highest caliber demonstrating, among other things, that impassioned learned debate about Islam's true nature on the part of pious and devoted believers is not a recent development; rather, it is perhaps in the nature of Islam itself. Nevin Reda's essay brings the Qur' an's literary nature to center stage with her examination of the Qur'an's intertextuality. The diversity with which Islamic texts and societies generate themselves is highlighted in Muhammed Rustom's study of the work of William Chittick, one of the major scholars of Islamic thought today. Liyakat Takim takes us into the world of Shi i figh, in a substantial analysis of the remarkably durable relationship between text and normative behavior so characteristic of Islam as such and Shi ism in particular. We are especially fortunate to have the outstanding article by Ingrid Hehmeyer, in which the categories of "water," "magic," "ortho- 
doxy," and "community" are juxtaposed in a way that suggests to us the Qur'anic symbolic or metaphorical equation of water/revelation/guidance. This article causes us to think deeply about the differences between true guidance or religion and mere magic. Walid Saleh's essay is a thoughtful and searching contemplation of the Qur'anic view of "death." One uses inverted commas here because it is clear that in Saleh's sensitive reading, death in the Qur'an is something of an illusion or misnomer. Finally, Omid Safi's eloquent and learned meditation on the nature of Islam and its texts is surely conditioned by a specific time, place, and social discourse and, paradoxically, expressive of something essential and unchanging.

The Qur'an is clearly addressed to something called "humanity." Indeed, it may be distinguished among the world's holy books by the degree and frequency with which it mentions, invokes, or addresses this particular topic. The generative or umbilical link between text and society makes itself manifest in both communities and individuals. In Islam's long and impressive venture, we can trace the effects of Qur'anic teaching in both social contexts and the nobility and creativity of individual lives. While we might not know exactly what "humanity" is, we can think of it as appearing in two forms, much like light itself, which science tells us can be studied as wave or particle, even if we do not know exactly what it is either. What Nwyia famously referred to as the "coranization of consciousness" has much in common with a process that religious studies identifies as "soul formation." And the vastly variegated richness of the cosmopolitanism that has typically characterized Muslim society may be thought of as both an achievement and an expression of this spiritual development.

Today, it is necessary to read the Qur'an first of all in light of itself and secondly in the context of a pluralistic global humanity whose future depends not upon triumphalism, conquest, and notions of cultural superiority, but rather upon the basic, and I might add, quintessentially Qur'anic axioms and verities of mutuality, cooperation, respect for cultural difference, and peace. To begin this reading, one must adopt the presupposition that the Qur'an is a profoundly meaningful, unified, and incomparably beautiful challenge to humanity to a kind of moral excellence frequently deemed unfashionable or unrealistic in the postmodern world. In short, one must see it as the epic of the world of Islam and Muslims, among whose main tasks is explaining its teachings to the rest of the world by example and other forms of peaceable and humane discourse, such as implementing the Book's challenging behavioral and moral standards. This epic's heroes include many of the prophets of the Hebrew Bible, several previously unknown prophets of Arabia, Jesus Christ, and Muhammad. Their shared epic drama is the moral regeneration of their respective societies: the journey from savagery and barbarity to culture and civilization. The Qur'an is a distinctive, poetic, and sacred discourse whose epic theme is the simultaneous transformation of the individual and society. History, according to the Qur'an, is defined and takes its shape precisely from humanity's serial and collective responses to those special moral and spiritual athletes known as prophets and divine messengers. To the degree that societies and individuals have successfully met the challenge of social justice, the cultivation of individual moral and ethical virtues, political harmony and mutual respect across cultures and languages, then to that extent a society may be deemed, according to the Qur'an, prosperous, productive, and righteous. 
The Qur'anic epic moves along first with the intervention, solicitude, and mercy of God, known to Arabs of whatever religion as Allah. It is assisted both by godly protagonists and such other supernatural entities as angels. But the primary focus is not only individual salvation (though this is certainly part of the program); rather, it is "salvation" on a communal scale. Thus the traditional epic's terms may be thought to be, in this instance, somewhat modified. There is another modification of the genre in the instance of the Qur'an. Anyone among the uninitiated who has read it ... and usually the uninitiated will read it in translation ... is struck by an apparent discontinuity of the text's flow: the rhyme and other intensely musical and cohesive aspects of the Arabic being absent in translation. The Qur'an seems to these readers to be a book without a beginning, a middle, and/or an ending. Additionally, while it is full of many discrete accounts and stories populated by heroes familiar and otherwise, these stories sometimes seem to begin in medias res and end just as abruptly ... frequently without "dramatic resolution." This has been one of the features emphasized in such a derogatory light in the past by a phobic reading of the text. Furthermore, its various narratives are separated by seeming non sequitur sections on legal obligations of the individual and the community, by prayers, by apocalyptic visions and, occasionally, mysterious and inscrutable allusions and disconnected Arabic letters. Thus, the whole represents a reading experience quite unparalleled in "the West."

It has been argued, beginning with Aristotle, that "dramatic resolution" is in fact quite artificial. Rather than mirroring "real life," it actually provides relief, catharsis, and/or escape from it. The Qur'an is not about escape. It may thus be thought ultimately a most verisimilar of epics in the way its chapters and verses - suras and ayas - chart and mirror the frequently disconcerting but nonetheless exquisitely familiar contrapuntal, polyrhythmic succession of lived experience's vagaries, those successes, reverses, triumphs and failures, loyalties, betrayals and mysteries - that nearly always seem to appear in medias res - in the average "real life." Thus in the Qur'an we have a sacred "epic verite." Those who believe in its truth and beauty sometimes marvel at the lack of imagination of those who cannot grasp this point.

Another important genre of literature, included in the Qur'an and later developed to a high degree of sophistication by Muslim intellectuals, is history. By the time Islamic history began to be sponsored officially - that is to say written - in Muslim realms, the community had developed and acquired many of the characteristic institutions and vocations that would continue to work themselves out over time. One key pattern of this early history has to do with the function of various severe crises in early Islamic history. Some of these crises have been characterized as political and some religious. For whatever reasons, these social, political, and religious crises occurred and left in their wake groups with varying theologies and visions of "the true Islam." By the early ninth century, aided by the vast wealth and power accumulated during the Abbasid dynasty's political successes, the court had mounted one of the most impressive "state"-sponsored scholarly enterprises up to that time: the attempt to collate, classify, and then translate the world's knowledge into Arabic. This project brought Muslims into direct contact with Greek (pagan) philosophy, and the Muslims - supremely confident of their place in the world as followers of the most recent divine revelation - set about coordinating this "foreign" knowledge with Qur'anic revelation. It was the supreme confidence of Islamic society that allowed it 
to take truth from whichever quarter it might be found. After all, according to Islam, all knowledge comes from God, a God who communicates such knowledge and truth to humans through specially chosen messengers. Therefore, truths and knowledge found outside of the Islamic cultural sphere might be imported, as long as it is recognized that these too will have their ultimate source in revelation, even if there exists no historical record of God's revelatory activity in the foreign culture. The allimportant epistemological presupposition was and is: if it is true, it must have its source in prophecy; if there is no record of such, say in ancient Greece, then the traces of such an event must have been lost forever. This applied to what we would refer to today as the two mutually exclusive spheres of science and religion. In classical Islam no such categorization is evident. It is absolutely inconceivable that any truth could occur outside the system of monotheistic prophecy. Just as such a spirit is exemplary of the classical and premodern cosmopolitanism that may be considered one of Islam's greatest achievements, it is important to remember that such cosmopolitanism has its genesis in the Qur'an itself, a Book that has much to offer a world struggling with globalism and cosmopolitanism in a new key today. Such a world would do well to seek insight from that same source in such verses as these:

There is no compulsion in religion: true guidance has become distinct from error, so whoever rejects false deities and believes in God has grasped the firmest hand-hold, one that will never break. God is all-hearing and allknowing. (Qur'an 2:256)

Another of His signs is the creation of the heavens and Earth, and the diversity of your languages and colors. There truly are signs in this for those who know. (Qur'an 30:22)

If God had so willed, He could have made them a single community, but He admits to His mercy whoever He will; the evildoers will have no one to protect or help them. (Qur'an 42:8-9)

O People, We created you all from a single man and a single woman, and made you into races and tribes so that you should recognize one another. In God's eyes, the most honored of you are the ones most mindful of Him: God is all-knowing, all-aware. (Qur'an 49:13)

Every community is sent a messenger, and when their messenger comes they will be judged justly; they will not be wronged. (Qur'an 10:47)

We shall show them Our signs in every region of Earth and in themselves, until it becomes clear to them that this is the Truth. Is it not enough that your Lord witnesses everything? (Qur'an 41:53) 